\title{
The Basic Stages of Preparing a Public Budget
}

\author{
Mustafa Hamad Al-Hakeem, Kahi Ilham Abdal \\ Alzaiem Alazhari University Khartoum North, Sudan \\ Erbil Polytechnic University Kurdistan Region- Iraq
}

\begin{abstract}
Budgeting is creating a plan to spend your money. Good budgeting is spending less than you are earning as you plan for your financial goals. Budgeting is the fundamental step in achieving financial literacy, and by extension, reaching financial security and freedom. Budgeting is the process of creating a plan to spend and invest your hard earned money wisely to meet your personal and financial goals in life. It should not be a mathematical exercise that we think we have to endure; rather, it is the result of selfassessment of our relationship with money and a necessary road map to steer us toward a higher standard and quality of living. The budget determines the general policy of the State and reflects its economic and development orientations and the partnership of all citizens with regard to their tax obligations or service rights. This is a strategic plan as a result of the expenditure study for years, taking into account the needs and potential of the ministries and the capacity to mobilize resources to cover the public expenditure of the State.
\end{abstract}

Keywords: Budgeting, Financial Management, Control, Beyond Budgeting

\section{Introduction}

Advanced Cost Accounting is a branch of accounting that deals with the collection, recording and tabulation of cost data in order to provide management information for the purpose of preparing the budget, Advanced cost accounting has a role in providing management with the information and knowledge necessary to provide performance control in our democratic parliamentary system, the budget is almost the most important responsibility (Bansal et al. 2009; Horngren et al. 2010; Prabhu \& Madanmohan 2014; Abdullah $\&$ Mohd 2015). The budget determines the general policy of the State and reflects its economic and development orientations and the partnership of all citizens with regard to their tax obligations or service rights. This is a strategic plan as a result of the expenditure study for years, taking into account the needs and potential of the ministries and the capacity to mobilize resources to cover the public expenditure of the State. Therefore, the budget in its modern concept, it is limited to the estimate of imports and expenses of the State.

\section{The research Importance}

The importance of studying the structure of the general budget in any country and shed light on them and identify their weaknesses in to help decision-makers and experts who draw up financial policies and those who contribute to the development of the reform strategy and the process of preparing the general budget and evaluate the actual performance and implementation and control of the draft budget. In this study author considered the research problem as the countries that rely on a single source of finance for their public revenues, and a lack of contribution to GDP and export capacity, suffer from economic instability. Research should be based on the hypothesis of imbalances in its structure, organizational aspect, public revenues and overhead.

\section{Objective of research}

To research has two main objectives, first, to analyze the reality of the structure of revenues and expenditures, and the second to develop a strategic vision for the reform of the budget. 


\section{Budget}

While Budget is an estimate of state expenditure and imports for a future fiscal year and, as is well known, requires authorization from the legislature the country concerned, and must be balanced between imports and expenditures even with a deficit Mali. And the balance in the linguistic definition and in all the dictionaries of the Arabic language of the tongue, Arabs to Upholstered: Balancing between the two things means looking at each other, and balance. (Rubin et al. 2004; Rabiyathul \& Ramyar 2019; Abdullah 2016)

\section{Preparation of a budget and the stages of implementation}

The process of preparing a public budget for any country, developed or developing, is a delicate process that requires a degree High technical planning and follow-up, given the multiplicity of departments and government units, in particular In a country such as Iraq, and the large sums included in that budget. The general budget in Iraq, as in most countries of the world, in several stages called a 'budget cycle' and are usually composed of four basic stages .

\section{Basic stages of preparing a public budget are}

\section{1- Stage of Preparation and preparation phase:}

After initial preparation by the relevant government agencies, This stages begins officially as soon as it is released A senior of the prime minister to prepare the draft budget law and budget projects of public institutions Independent. This adult includes instructions to prepare the budget, and the dates of submission of all requirements of Statements of expenditure, income, job formation, etc. to the General Budget Department. The ministries Governmental departments and the institutions in turn to circulate to their various departments to submit their forecasts for their programs and its activities for the next Finance year. After that the proposals are discussed with directors of departments, units and councils of the governorates, Make any proposed amendments and draw up a final draft budget, by specialists in the Department.

\section{2- Stage of Accreditation and approval}

The more precise cycle stages and sensitivity are due to being the last station, to discuss the draft budget law before its adoption and approval for implementation, this stage began with a statement (Budget Letter) including the Government's policy and program of action during the next Finance year, this is done immediately after referring the draft budget law to the House of Representatives. After receipt of the draft budget law, The House of Representatives shall refer it to the Finance and Economic Committee Which will study the budget and discuss with officials in the executive branch where the recommendations are subsequently raised Rapporteur to the House of Representatives.

\section{3- Stage of Implementation}

This stage begins with the issuance of the implementation of the budget, and public and private financial orders, as well as follow-up performance and performance evaluation, the implementation stage begins at the moment of publication of the General Budget Law in the Official Gazette, Beginning with the practical procedures for the implementation phase. In the case of an inquiry by the concerned government agencies on any problem encountered during the implementation of the budget, both in respect of the expenditure on the items concerned, Or request for the treatment of any deficit in the allocation of materials, Or transfer of allotments from one item to another, Or request additional allocations (budget annex, etc.), Then they do These agencies use the Public Budget Department, which in turn investigates these inquiries or requests Response or presentation at the highest levels of competence. In many cases, ministries and government departments are forced to implement the budget, to transfer allocations from one item to another to cover their actual needs in light of the actual disbursement during the year (Bohn \& Inman 1996; Othman et al. 2015; Rabiyathul \& Ramyar 2019).

\section{4- Stage of monitoring implementation and evaluation}

Control plays an important role in the budget cycle in order to ensure that the implementation of the budget was, Consistent with what has been estimated and allocated in all items and identify any deviations to be processed in time the appropriate. The responsibility for monitoring the implementation of the budget lies 
primarily with the legislative authority, which is assured In turn, that the executive branch adheres to the bases of collection and expenditure based on periodic reports submitted to it Specialized departments in financial control. In turn, the Audit Office submits an annual report to the National Assembly containing its comments on the departments, and institutions that audit their accounts with the statement of the violations committed and their liability, The Ministry of Finance also submits an annual report containing the final accounts For the fiscal year, which includes a comparison of what is stated in the budget law with actual expenditure.

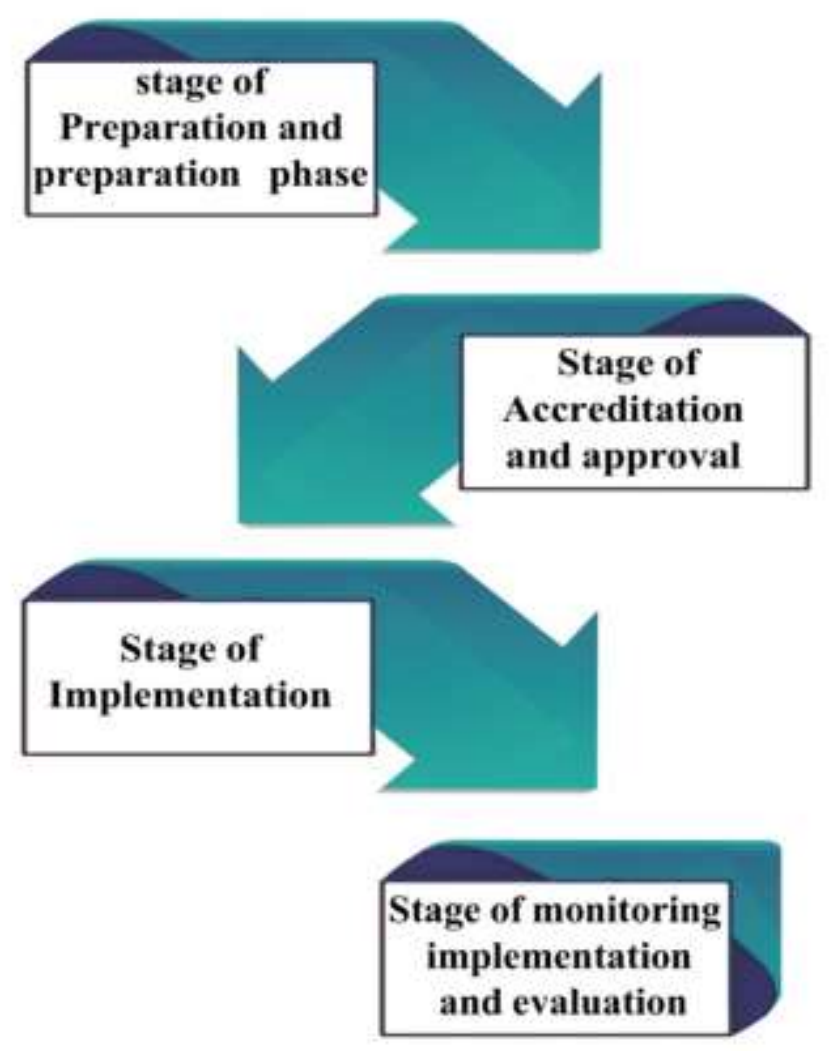

Figure 1: Basic Stages of Preparing a Public Budget

\section{Types of budget}

There are many type budget but the Modern trends of type budgets the public are:

\section{1- Items Budget}

Also known as the traditional budget, its name derives from the way it is presented in the form of items according to the purpose of the expenses, A digital expression has been put on the items needed to operate the administrative unit, such as rents, salaries and wages, office supplies and other items, The budget items focuses on the accounting function and control over items of expenditure, not on the amount of services provided, Budgeting items that help the accounting system in the controls before and after spending to ensure that the provisions allocated to the item are not exceeded.

The advantages of using budget items is easily characterized by numbers, presentation, implementation and control, As well as easy to understand by the parties used, helps to use the concept of liability accounting, and its data are comparable for several consecutive years where it is easy to know the direction of expenditure or collection.

Disadvantages of using budget items are that they lead to excessive control over the expense of the planning and evaluation process, they neglect scientific planning, and depends on building on current expenditure levels and patterns, where activities are transferred from year to year, whether these activities are appropriate or inappropriate, This leads to a lack of clarity on the objectives that different departments must achieve, They are also concerned only with short-term needs.

\section{2-Programs \& Performance budget}


They are set according to the purpose of the activity, here lies the reason for the shift from budget items, to Budgeting of Programs \& Performance, Where it is ensured that the administration performs its duties efficiently and effectively, The budget is prepared by dividing the company's activities into specific programs, each of which aims to achieve a specific goal, budget is prepared for each program on the one hand, and this provides the institution with a better decision-making base (Alesina et al. 1999; Mohamed, 2004; Nambirajan \& Prabhu 2011).

Advantages of using Programs \& Performance budget, It links management activities to the objectives set, and divides operations into functions, Jobs to programs, and then divides each program into a range of activities that achieve program objectives, It is the regulatory tool for management activities and provides information to judge the efficiency of performance and the application of the principle of accountability and responsibility.

Disadvantages of using Programs \& Performance budget the difficulty of measuring many activities in the form of output units and determining their cost, which is reflected in the identification of units of measurement and performance analysis, the preparation and implementation of this kind of budgets need to be trained and qualified staff scientifically and practically.

\section{Budget planning and programs}

The idea of this budget is mainly aimed at to improve and rationalize the decision-making process Best practices, distribution and use of possibilities Available in the country, It was defined as a planning tool And a means of making decisions about the trade-off Alternative programs needed to achieve certain goals or Adjusting those objectives to justify the plan's decisions Government programs and activities are seen adjust means aimed at transforming public resources of the state or factors of production into final products (Joshi, et al. 2003; Curtis \& Wu 2000; Fang 2014)

This type of budget is based on Long-term considerations, Analysis of cost and benefit systems and statement of possible alternatives for allocation Resources.

\section{Advantages}

This type of budget is rational scientific approach to decision making, flexibility and sequencing. It does not adhere to the annual basis, but goes beyond specific objectives that may require a period of more than one year, and is comprehensive and focuses on achieving the main objectives of the establishment.

\section{Disadvantages}

The disadvantage of the budget planning and programs that they need to high competencies and trained and some of the objectives difficult to measure, as they are interested in strategic planning, they often concern the higher departments and not the lower departments in the establishment.

\section{Zero budgets}

Is a budget that is based on the beginning of It is known as a system that assumes no The existence of any expenses or services at the beginning of order Get a set of results or outputs Taking into account the minimum cost and evaluation For this reason, the duration of the expenditure is effective, The kind of budget under which it is omitted Programs at the beginning of each financial period Review all programs from the ground up from scratch And to develop a new scheme of allocations without being Any program has preference over other programs This method is summarized by each organizational unit To re-submit all its projects and what is contained therein Programs and activities based on the comparison of interest earned With the cost achieved, It helps managers And officials to solve the problems they face While providing historical cost data and metrics Performance and comparison of similar activities (Deaton \& Irish 1984; Chen Jiali 2012; Harkness \& Green 2004).

Advantages This type of budget they focus on decentralization, and allow wider participation of decision makers, And increase the effectiveness of channels of communication between the parties involved, this method increases the accuracy of setting goals and raise efficiency due to the process of continuous assessment, It also provides greater flexibility for senior management to redeploy resources and develop staff skills by involving them in the planning and evaluation process.

Disadvantages of the basic zero budget in the high costs of their application and that they need to prepare time and effort greater than the traditional budget, It also requires a lot of analysis and study, and it needs a 
large amount of information needed to conduct the analysis process, And requires trained and qualified cadres to prepare and analyze data related to them.

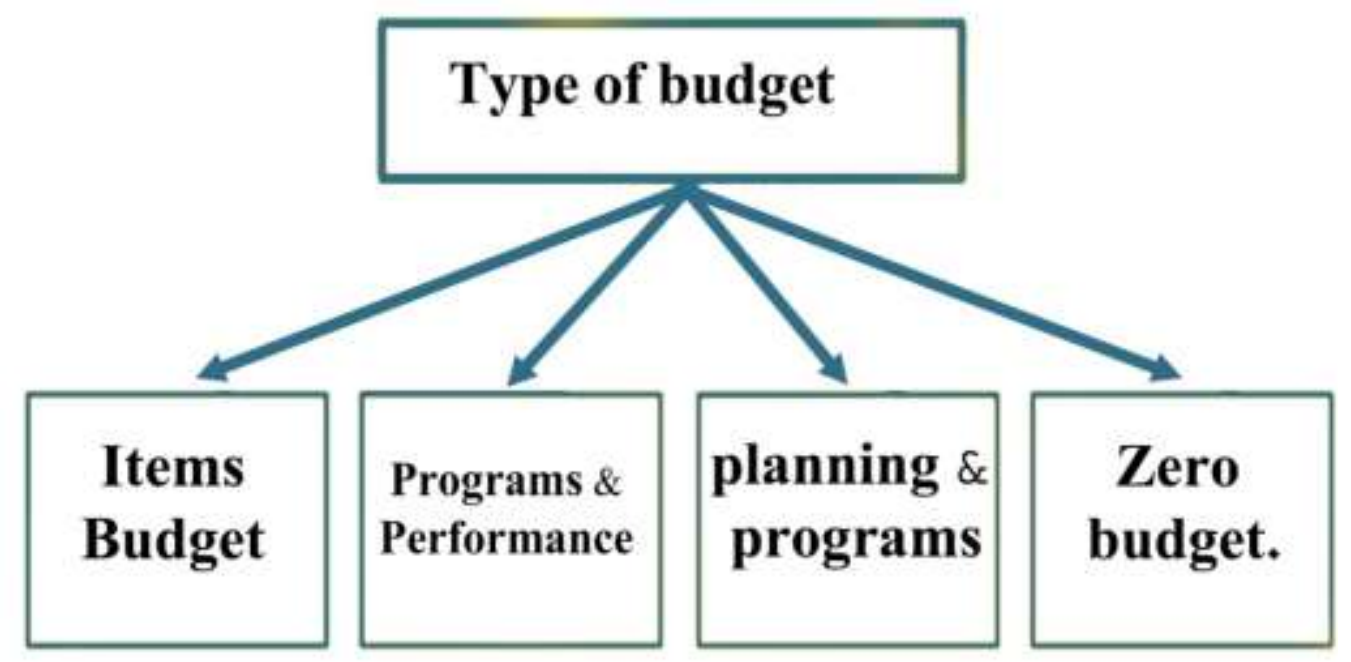

Figure 2 Type of budget

\section{Conclusion}

This research examines the role of accounting and the costs of control in the preparation of the budget and the stages of preparing the budget and the types of budget and the advantages and disadvantages of each type, budget preparation is the functions of government, and the budget is a good Guide of good government guide, budget for one year, And revenue, if the revenue of the largest expenditure is the budget surplus, if the expenses of the largest revenue is the budget deficit.

\section{References}

[1] Abdullah NN, Mohd, F (2015) Chinese Economic Activities and Interests in Developing Countries. Australian Journal of Basic and Applied Sciences 9(25): 79-86.

[2] Abdullah NN (2016) The Role of Foreign Direct Investment in Developing Kurdistan's Economy (Master Thesis). Universiti Utara Malaysia, Sintok.

[3] Alesina A, Hausmann R, Hommes R, Stein E (1999) Budget institutions and fiscal performance in Latin America. Journal of development Economics 59(2): 253-273.

[4] Bansal SC, Sharma, Lata (2009) New Challenges of Accounting and Auditing in Environment in India, Revista Universo Contábil 5(1): 88-99.

[5] Bohn H, Inman RP (1996) Balanced-budget rules and public deficits: evidence from the US states. In Carnegie-Rochester conference series on public policy 45: 13-76.

[6] Chen Jiali. (2012) Research on Electronic Commerce Network Financial Accounting Development. Enterprise Economy 06: 128-132.

[7] Curtis MB, Wu FH (2000) The Components of a Comprehensive Framework of Internal Control. CPA Journal.

[8] Deaton A, Irish M (1984) Statistical models for zero expenditures in household budgets. Journal of Public Economics 23(1-2): 59-80.

[9] Fang Yong. (2014) Research Impact of Electronic Commerce on the Financial Accounting Development. Managers 36: 1-2.

[10] Harkness MD, Green BP (2004) E-Commerce's Impact On Audit Practices. Internal Auditing 19(2), 28-36.

[11] Horngren CT, Foster G, Datar SM, Rajan M, Ittner C, Baldwin AA (2010) Cost accounting: A managerial emphasis. Issues in Accounting Education 25(4): 789-790.

[12] Joshi P L, Al-Mudhaki J, Bremser WG (2003) Corporate budget planning, control and performance evaluation in Bahrain. Managerial Auditing Journal 18(9): 737-750.

[13] Mohamed Tayseer Al Rajabi, Administrative Accounting, 3rd Edition 2004. 
[14] Nambirajan T, Prabhu M. (2011) Competitiveness of Manufacturing Industries in Union Territory of Puducherry (India): A Critical Analysis. International Journal of Business Economics \& Management Research 2 (5): 54-65.

[15] Othman M, Saud MB, Mat Isa MA, Abdullah NN (2015) The Conceptual Assessment of Malaysian Entrepreneurship Environment and EO Economic Contribution. Journal of Resources Development and Management 20: 15-20.

[16] Prabhu M, Madan Mohan G (2014) A study on stress among university students in India. International Journal of Business and Administration Research Review 1(5): 21-33.

[17] Rabiyathul Basariya S, Ramyar Rzgar Ahmed (2018) A Study on Consumer Satisfaction and Preference of Color TV Brands in Chennai City. International Research Journal of Management and Commerce 5(11): 47-60.

[18] Rabiyathul Basariya S, Ramyar Rzgar Ahmed (2019) The Influence of Adventure Tourism Activities' in promoting tourism business in mountain stations. African Journal of Hospitality, Tourism and Leisure 8 (2): 1-10.

[19] Rubin RE, Orszag PR, Sinai A (2004) Sustained budget deficits: the risk of financial and fiscal disarray. In AEA-NAEFA Joint Session, Allied Social Science Associations Annual Meetings. 